\title{
Frankfurter sausage texture is affected by using isolate, concentrate and flour of Lupinus albus and pork skin proteins
}

\author{
${ }^{1}$ Güemes-Vera, N., ${ }^{2}$ Zamora-Natera, J.F. and ${ }^{1 *}$ Soto, S.S. \\ ${ }^{1}$ Instituto de Ciencias Agropecuarias. Universidad Autónoma del Estado de Hidalgo. Ave. Universidad s/n. \\ km 1. Ex-Hacienda de Aquetzalpa. Tulancingo, Hidalgo. México. C.P. 43600 \\ ${ }^{2}$ Departamento de Botánica y Zoología. Centro Universitario de Ciencias Biológicas y Agropecuarias. \\ Universidad de Guadalajara. Camino Ing. Ramón Padilla Sánchez \# 20100, CP 455110. Zapopan, Jalisco \\ México
}

\begin{abstract}
Article history:
Received: 8 December 2017

Received in revised form: 9 January 2018

Accepted: 9 January 2018

Available Online: 16 January 2018
\end{abstract}

\section{Keywords:}

Frankfurters,

Lupinus,

Collagen,

Texture

\section{DOI:}

https://doi.org/10.26656/fr.2017.2(3).290

\begin{abstract}
Frankfurters are typically produced using a wide range of ingredients comprised of various animal or vegetable proteins, including legume and oleaginous seeds, mainly soybean. Lupinus and collagen from pork skin have several functional properties which contribute to stabilizing and forming emulsions. The aim of this study was to determine the effect of collagen obtained from pork skin and isolate, concentrate or flour of Lupinus on texture frankfurters measured using different probes attached to a texture analyzer. Frankfurters were prepared by adding flour, isolated and concentrate of Lupinus in proportion of 0.5 , 1.0, 1.5 y 2.0; and collagen solutions obtained from pork skin $(0,1,2$ y $3 \%)$. The proximal analysis in isolate, concentrate, and flour of Lupinus, and collagen in pork skin solutions were measured. Textural properties were evaluated in frankfurters. The results showed no differences $(\mathrm{P}>0.05)$ between Lupinus flour, protein isolate and concentrate vs control in firmness and cohesiveness. However, higher values for resilience and springiness than sausages prepared with Lupinus. Warner Bratzler firmness values using 3\% collagen were lower than other treatments. The treatment had less firmness was AIS-100, and the least cohesiveness was CON-150, control had the most resilience, and CON-100 treatment was the most adhesiveness. The sausages added with isolate, concentrate or flour of Lupinus albus in quantities of 50,100 or $150 \mathrm{~g}$, respectively produce an excellent texture meat product. When collagen is used in $3 \%$ the texture of sausages is firm and should be recommended to use for industrial production of meat products.
\end{abstract}

\section{Introduction}

Sausages composition is diverse; pork, turkey or poultry are used, also it is added with several additives, e.g. phosphates, gums and other ingredients. Back fat and meat extenders are usually used to produce sausages (Abdolghafour and Saghir, 2015). There are several nonmeat proteins used in the preparation of frankfurters and other meat products which include starches, vegetable protein, dairy protein, antioxidant, extenders and so on (Tarté, 2009; Abdolghafour and Saghir, 2015). Soybean protein isolate is one of the most used in meat technology (Egbert and Payne, 2009). Another protein used is collagen which improves sensory properties, and enhances gelling, water holding capacity and increase protein content (Sousa et al., 2017).

Collagen is added to meat products as connective tissue, but it is physical form, composition, and stability to heat must be important for use in emulsified products (Prabhu et al., 2004). When this protein is used in meat products, it must be purified or hydrolysate (Tarté, 2009). Prabhu et al. (2004) suggest that collagen improved protein functionality through facilitating immobilized free water and increasing the stability of the product. Collagen used at low levels is effective in reducing the shortening and texture control of meat products. An alternative to using soybean is a leguminous named Lupinus, which has been used as food for humans since ancient times (Prusinski, 2017). Lupinus seed has $42 \%$ protein in some varieties (Schumacher et al., 2011). Lupinus proteins improve nutritional quality, texture, and color of food products (Prusinki, 2017). The functional properties of these proteins are to facilitate food emulsions (Porras-Saavedra et al., 2013) and contribute to sausage structure. Pork skin proteins increase the firmness and stability of meat 
products. Collagen, the main protein skin, becomes gelatin during heat treatment. Gelatin is commonly used in cooked sausages due improve firmness (Feiner, 2006). The aim of this study is to determine the effect of collagen, Lupinus flour, protein isolate and concentrate on frankfurters texture using different attachments to measure them.

\section{Materials and methods}

2.1 Collagen, Lupinus flour, and protein isolate preparation

Collagen was obtained from pork skin incubated at $80^{\circ} \mathrm{C}$ for 4 hours in a $1.5 \mathrm{M} \mathrm{NaCl}$ solution at $\mathrm{pH} 9$. Lupinus albus flour was detoxified by exposing the seeds to hot water $\left(95^{\circ} \mathrm{C}\right)$ for five minutes and alkaloids were removed using continuous water for 15 hours (CarvajalLarenas et al., 2016). The seeds were the sun-dried. They were then ground (Krups model 203) and sieved (Standard Testing Sieve No. 25, Tyler equivalent 24 mesh, $0.710 \mathrm{mM}$ ). The flour was defatted using hexane $(1: 4 \mathrm{w} / \mathrm{v})$ for $8 \mathrm{~h}$ under constant shaking at $8^{\circ} \mathrm{C}$. The flour was then dried in a chamber at $50^{\circ} \mathrm{C}$ to remove any solvent residues. In order to obtain Lupinus protein isolate, the flour was washed three times for 30 minutes each time at room temperature using isopropyl alcohol $80 \%$ and $60 \%$. The collagen was analyzed by hydroxyproline content. Lupinus flour and protein isolate was evaluated for soluble protein. The proximate analysis (dietary fiber, ash, nitrogen content as protein, fat) in all samples.

\subsection{Frankfurter sausage preparation}

Meat batters were formulated using a typical frankfurter sausage base, using pork meat without any seasoning ingredients (Table 1). The lean pork meat was purchased from local market. Ground meat, salt, sodium nitrate, commercial phosphates mixture and a third part ice were mixed for one min in a Dito Sama K35 cutter (Dito Sama, Aubusson, France). Back fat was added and emulsified for one minute with another third of ice for two minutes. Collagen, Lupinus flour, protein isolate or concentrate and the remainder of the ice were added and homogenized for another three minutes, controlling the temperature to less than $10^{\circ} \mathrm{C}$. Meat batters were manually stuffed into polyamide casings, cooked to an internal temperature of $68^{\circ} \mathrm{C}$, maintained for $15 \mathrm{~min}$, cooled in an ice bath, stored at $4^{\circ} \mathrm{C}$ for $24 \mathrm{~h}$, vacuum packed and kept under refrigeration until analysis. A total of three batches $(0.5 \mathrm{~kg})$ of each treatment were manufactured.

2.3 Texture profile analysis (TPA) of sausages prepared using collagen, flour, concentrate or protein isolate from Lupinus

Samples were kept in refrigeration 24 hours before analysis. The sausage samples were then cut $2 \mathrm{~cm}$ thick, $2.5 \mathrm{~cm}$ diameter and subjected to two cycles compression test and analyzed using a a texture analyzer (TA.HDi Texture Analyzer, TA Instruments, Surrey, UK). Five samples of each treatment were compressed to $75 \%$ of their height according to Bourne (1978). A Perspex probe of $2.5 \mathrm{~cm}$ diameter attached to a load cell of $50 \mathrm{~kg}$ was compressed twice at a speed of $1 \mathrm{~mm} / \mathrm{sec}$. TPA parameters were obtained as follows: hardness, cohesiveness, resilience, and springiness.

\subsection{Warner-Bratzler analysis of sausages prepared using collagen, flour, concentrate or protein isolate from Lupinus}

A V-shaped blade with a thickness of $3.20 \mathrm{~mm}$, the height of $125 \mathrm{~mm}$ and width of $70 \mathrm{~mm}$ was assembled to the TA.HDi Texture Analyzer with an attached a load cell of $50 \mathrm{~kg}$. A tested sample was placed on the plate, under the v-blade, cutting down at a pre-test speed of 2 $\mathrm{mm} / \mathrm{s}$, and $1.0 \mathrm{~mm} / \mathrm{s}$ test speed. The analyzer had

Table 1. Frankfurter sausages formulation used in collagen and Lupinus derivates treatments.

\begin{tabular}{|c|c|c|c|c|c|c|c|c|}
\hline \multirow{2}{*}{ Ingredients } & \multirow{2}{*}{ Control } & \multicolumn{3}{|c|}{$\begin{array}{l}\text { Collagen treatment } \\
\text { (Trial 1) }\end{array}$} & \multicolumn{4}{|c|}{ Lupinus treatment (Trial 2) } \\
\hline & & $\mathrm{T} 1$ & $\mathrm{~T} 2$ & $\mathrm{~T} 3$ & T1 & $\mathrm{T} 2$ & $\mathrm{~T} 3$ & $\mathrm{~T} 4$ \\
\hline Pork meat (\%) & 60 & 60 & 60 & 60 & 60 & 60 & 60 & 60 \\
\hline Pork Back fat (\%) & 15 & 15 & 15 & 15 & 15 & 15 & 15 & 15 \\
\hline Water (\%) & 25 & 25 & 25 & 25 & 25 & 25 & 25 & 25 \\
\hline Salt (g) & 1.5 & 1.5 & 1.5 & 1.5 & 1.5 & 1.5 & 1.5 & 1.5 \\
\hline Phosphates mix (g) & 0.26 & 0.26 & 0.26 & 0.26 & 0.26 & 0.26 & 0.26 & 0.26 \\
\hline Nitrites (g) & 0.16 & 0.16 & 0.16 & 0.16 & 0.16 & 0.16 & 0.16 & 0.16 \\
\hline Flour $(\mathrm{g})$ & 4 & 4 & 4 & 4 & 4 & 4 & 4 & 4 \\
\hline Carrageenan (g) & 1.5 & 1.5 & 1.5 & 1.5 & 2.5 & 2 & 1.5 & 1 \\
\hline Soybean isolate $(\mathrm{g})$ & 5 & 0 & 0 & 0 & 0 & 0 & 0 & 0 \\
\hline Collagen, Lupinus flour, protein isolate or concentrate (g) & 0 & 5 & 10 & 15 & 0.5 & 1 & 1.5 & 2.0 \\
\hline
\end{tabular}


attached a 50-kg cell load and was configuring to run a test speed $1 \mathrm{~mm} / \mathrm{s}$ and $2 \mathrm{~mm} / \mathrm{s}$ before and after the test. The samples used for this analysis were cut $100 \mathrm{~mm}$ of large and $25 \mathrm{~mm}$ diameter and each sample was assessed five times.

2.5 Kramer analysis of sausages prepared using collagen, flour, concentrate or protein isolate from Lupinus

Kramer device involves a combination of shearing and compression forces; the determinations were performed as described by Szczesniak (1963). Samples were sheared using a TA texture analyzer (TA Instruments, Surrey, UK) with a 10-blade Kramer shear compression attached, $3 \mathrm{~mm}$ thick and $100 \mathrm{~cm}$ wide blades that down through a box having a corresponding number of slots using a $50 \mathrm{~kg}$ load cell. The maximum peak force $(\mathrm{kg})$ was recorded as the shear force required shearing through the sample.

\subsection{Statistical Analysis}

To evaluate collagen effect on texture properties of frankfurter sausages, a one-way analysis was used $(0,1$, 2 у 3\%). Lupinus flour, concentrate, and protein isolate was analyzed by two-way analysis using percentage used $(0.5,1,1.5$ y $2 \%)$ and Lupinus isolate, concentrate and flour as factors. All results were evaluated using a PROC GLM procedure and a Tukey test comparison by means of SAS software (SAS, 1999).

\section{Results and discussion}

\subsection{Composition of Lupinus flour, protein isolate,} concentrate and collagen extract

Table 2. Proximal analysis of Lupinus seed, flour, concentrate and collagen content of pork skin.

\begin{tabular}{lccccc}
\hline \multirow{2}{*}{ Analysis } & \multicolumn{4}{c}{ Lupinus derivates } & Pork skin \\
\cline { 2 - 5 } & Seed & HD & HDD & C & extract \\
\hline Moisture (\%) & 9.0 & 9.0 & 9.9 & 9.6 & ND \\
Ash (\%) & 3.8 & 2.5 & 2.7 & 2.5 & ND \\
Protein (\%) & 34.6 & 41.5 & 43.8 & 83.1 & 57.92 \\
Dietary fiber (\%) & ND & 7.1 & 8 & ND & ND \\
Fat (\%) & 14.53 & 16 & 0 & 0 & ND \\
Collagen (g/100g) & ND & ND & ND & ND & 53.1 \\
\hline
\end{tabular}

$\mathrm{HD}=$ Detoxified flour, HDD $=$ Detoxified and defatted flour, $\mathrm{C}=$ Protein concentrate, $\mathrm{ND}=$ Non-determined

Proximate analysis of Lupinus flour, protein isolate and collagen content of extract of pork skin are shown in Table 2. Moisture values were between 9 and $9.95 \%$, ash content was higher in seed than flour or concentrate of Lupinus. Ruiz and Sotelo (2001) reported similar results, but Güemes-Vera (2012) reported lower values. The protein percentage of concentrate of Lupinus was
83.12\%, Ruiz and Sotelo (2001); Fraser et al. (2005) reported 40.73 and $36 \%$ for wild Lupinus and Lupinus angustifolius, respectively. Güemes-Vera (2012) analyzed Lupinus mutabilis and found 49.4, 70 and $93.5 \%$ of protein for flour, concentrate and isolate. The average fat was 14.53 and $16 \%$, respectively. Ruiz and Sotelo (2001) reported $7.09 \%$ for wild Lupinus.

3.2 Effects of utilize Lupinus flour, protein isolate and concentrate in frankfurter texture

Results from TPA analysis are shown in Table 3. All variable analyzed showed differences $(\mathrm{P}<0.05)$ between treatments. Frankfurters elaborated using $2 \%$ of Lupinus protein concentrate had higher firmness than control. This effect is due to higher protein content and better water holding capacity; whereby both of these factors contribute to be a stable emulsion.

The adhesiveness was similar in all the treatments although the CON-150 showed greater value $(\mathrm{P}<0.05)$. With respect to the resilience were significant differences $(\mathrm{P}<0.05)$ between the witness and the other treatments. Springiness showed differences $(\mathrm{P}<0.05)$ but only between CON-200 and the rest of the treatments. With regard to other studies in which diverse vegetable products were added to sausages with the aim of modifying their functional properties, the serum protein and the tapioca starch used in sausage manufacturing increased firmness, adhesiveness, gumminess, and chewiness. However, neither the effect on resilience nor on the cohesiveness of the product were observed (Hughes et al., 1998). Osburn and Keeton (2004) used different flour levels of Konjac in the elaboration of lamb inlays with the purpose of reducing the amount to be used. When the TPA was performed, differences in hardness, chewiness, and gumminess, indicating that the fat diminution resulted in a dense product but with a greater proportion of myofibrillar protein for the intermolecular union, and for this reason a greater force for compression was required.

\subsection{Effect of the protein inclusion extracted from pig skin on the sausage texture using the knife of Warner Bratzler.}

Table 3 shows the results obtained for texture using Warner Bratzler blade where significant differences were observed $(\mathrm{P}<0.05)$. The sausages which were incorporated with $3 \%$ pig skin proteins showed the lowest firmness. These results were similar to those reported by Schilling et al. (2005), whose reported that the addition of $1.5 \%$ of collagen of chicken, in chicken products did not find any differences in the proteinprotein union and concluded that collagen can improve the functional nature of proteins. Prabhu et al. (2004) 
Table 3. Texture profile analysis of frankfurters added with Lupinus derivates.

\begin{tabular}{ccccc}
\hline Treatment & Hardness $(\mathrm{g})$ & Cohesiveness & Resilience & Springiness (negative) \\
\hline Control & $1196.15 \pm 90.38^{\mathrm{b}}$ & $0.34 \pm 0.01^{\mathrm{ab}}$ & $0.95 \pm 0.09^{\mathrm{a}}$ & $39.39 \pm 4.29^{\mathrm{a}}$ \\
AIS-50 & $1016.31 \pm 257.50^{\mathrm{b}}$ & $0.29 \pm 0.03^{\mathrm{ab}}$ & $0.23 \pm 0.01^{\mathrm{b}}$ & $52.06 \pm 36.70^{\mathrm{ab}}$ \\
AIS-100 & $776.70 \pm 63.03^{\mathrm{c}}$ & $0.24 \pm 0.02^{\mathrm{ab}}$ & $0.20 \pm 0.01^{\mathrm{b}}$ & $51.82 \pm 19.47^{\mathrm{ab}}$ \\
AIS-150 & $1416.10 \pm 182.79^{\mathrm{ab}}$ & $0.20 \pm 0.24^{\mathrm{b}}$ & $0.21 \pm 0.01^{\mathrm{b}}$ & $83.13 \pm 30.56^{\mathrm{ab}}$ \\
AIS-200 & $1469.83 \pm 81.02^{\mathrm{ab}}$ & $0.36 \pm 0.12^{\mathrm{a}}$ & $0.21 \pm 0.01^{\mathrm{b}}$ & $88.51 \pm 13.57^{\mathrm{ab}}$ \\
CON-50 & $994.39 \pm 3.71^{\mathrm{b}}$ & $0.26 \pm 0.05^{\mathrm{ab}}$ & $0.20 \pm 0.03^{\mathrm{b}}$ & $67.06 \pm 37.97^{\mathrm{ab}}$ \\
CON-100 & $1300.93 \pm 56.94^{\mathrm{ab}}$ & $0.25 \pm 0.03^{\mathrm{ab}}$ & $0.21 \pm 0.01^{\mathrm{b}}$ & $135.14 \pm 87.23^{\mathrm{ab}}$ \\
CON-150 & $1141.44 \pm 11.26^{\mathrm{bc}}$ & $0.13 \pm 0.04^{\mathrm{b}}$ & $0.18 \pm 0.02^{\mathrm{b}}$ & $179.51 \pm 147.01^{\mathrm{b}}$ \\
CON-200 & $1521.94 \pm 49.99^{\mathrm{a}}$ & $0.43 \pm 0.13^{\mathrm{a}}$ & $0.19 \pm 0.02^{\mathrm{b}}$ & $82.34 \pm 51.93^{\mathrm{ab}}$ \\
HAR-50 & $1184.33 \pm 36.13^{\mathrm{b}}$ & $0.30 \pm 0.02^{\mathrm{ab}}$ & $0.24 \pm 0.00^{\mathrm{b}}$ & $86.27 \pm 53.19^{\mathrm{ab}}$ \\
HAR-100 & $897.51 \pm 203.77^{\mathrm{c}}$ & $0.21 \pm 0.03^{\mathrm{b}}$ & $0.18 \pm 0.00^{\mathrm{b}}$ & $40.35 \pm 8.44^{\mathrm{a}}$ \\
HAR-150 & $1165.82 \pm 5.48^{\mathrm{bc}}$ & $0.20 \pm 0.03^{\mathrm{b}}$ & $0.16 \pm 0.03^{\mathrm{b}}$ & $82.76 \pm 1.56^{\mathrm{ab}}$ \\
HAR-200 & $1039.8 \pm 0.78^{\mathrm{bc}}$ & $0.20 \pm 0.01^{\mathrm{b}}$ & $0.30 \pm 0.15^{\mathrm{b}}$ & $113.21 \pm 1.26^{\mathrm{ab}}$ \\
\hline
\end{tabular}

Different letters in same column indicate differences significantly $(\mathrm{P}<0.05)$.

also reported that no difference exists between treatments used in ham and sausages. Nevertheless, it was observed that as the levels of collagen in the product are increased, the values of maximum cut force increased. Choe et al. (2013) found that the addition of gelatin into frankfurter sausages increases hardness. However, Schilling et al. (2003) found that the use of collagen increases protein union using meat PSE. Several vegetal products modify functional properties of sausages. The tapioca starch is used in sausage manufacture for increase firmness, adhesiveness, gumminess, and chewiness (Hughes et al., 1998). Osburn and Keeton (2004) reported that Konjac flour in sausage lamb decreases fat quantity, firmness, chewiness, and gumminess. When fat is low, the product is firm, and higher myofibrillar protein content is needed for intermolecular union.

\subsection{Effects of protein extracted from pork skin on sausage texture using Warner bratzler blade}

Sausage texture using collagen from pork skin is shown in Table 4. The firmness of the sausage was different between treatments $(\mathrm{P}<0.05)$, but there was no stress $(\mathrm{P}>0.05)$. Sausages added with $3 \%$ of pork skin protein showed less firmness. Chilling et al. (2005) observed that collagen from poultry improved the protein functionality and there was no interaction between proteins. Prabhu et al. (2004) showed no differences between treatments used in ham and sausages preparation. However, when collagen percentage was increased firmness values were higher. Kenney et al. (1992) reported restructured beef products using washed muscle mixed with $0.2 \% \mathrm{NaCl}$ and observed that washing enhance instrumental texture measures of product.
Table 4. Effect of protein skin on texture of frankfurter.

\begin{tabular}{ccccc}
\hline \multirow{2}{*}{ Treatment } & \multicolumn{2}{c}{ Kramer cell } & \multicolumn{2}{c}{ Warner Bratzler } \\
\cline { 2 - 5 } & $\begin{array}{c}\text { Maximum } \\
\text { Force }(\mathrm{g})\end{array}$ & $\begin{array}{c}\text { Firmness } \\
(\mathrm{g} / \mathrm{s})\end{array}$ & $\begin{array}{c}\text { Maximum } \\
\text { Force }(\mathrm{g})\end{array}$ & $\begin{array}{c}\text { Firmness } \\
(\mathrm{g} / \mathrm{s})\end{array}$ \\
\hline 0 & 10377 & 121354 & $759.41^{\mathrm{a}}$ & 9374 \\
1 & 12129 & 133281 & $776.49^{\mathrm{a}}$ & 9604 \\
2 & 9671 & 115689 & $717.81^{\mathrm{a}}$ & 9533 \\
3 & 29809 & 83794 & $522.37^{\mathrm{b}}$ & 7589 \\
\hline
\end{tabular}

Different letters in same column indicate differences significantly $(\mathrm{P}<0.05)$.

\section{Conclusion}

The use of 3\% of collagen produces less firmness of sausages using Warner Bratzler blade. There were no differences between the isolate, the concentrate or the flour of Lupinus in terms of control in firmness, cohesiveness, and springiness. The treatment which showed the least firmness was AIS-100, and the least cohesiveness was CON-150, control had the most resilience while CON-100 was the most adhesive treatment. The sausages added with isolate, concentrate or flour of Lupinus albus in quantities of 50, 100 or 150 $\mathrm{g}$, respectively produce an excellent texture meat product. When $3 \%$ collagen was used, the texture of sausages is firm and should be recommended to be used for industrial production of meat products.

\section{Conflicts of Interest}

The authors declare that there are no conflicts of interest. 


\section{Acknowledgments}

We would like to acknowledge to Ma. Guadalupe Alvarado and Edgar Garrido for technical support of this work.

\section{References}

Abdolghafour, B. and Saghir, A. (2015). Development in sausage production and practices-A review. Journal of Meat Science and Technology, 2, 40-50.

Bourne, M.C. (1978). Texture profile analysis. Food Technology, 35, 62-66.

Carvajal-Larenas, F.E., Linnemann, A.R., Nout, M.J.R., Koziol, M. and van Boekel, M.A.J.J. (2016). Lupinus mutabilis: composition, uses, toxicology, and debittering. Critical Reviews in Food Science and Nutrition, 56, 1454-1487. https:// doi.org/10.1080/10408398.2013.772089

Choe, J.H., Kim, H.Y., Lee, J.M., Kim, Y.J. and Kim, C.J. (2013). Quality of frankfurter-type sausages with added pig skin and wheat fiber mixture as fat replacers. Meat Science, 93, 849-854. https:// doi.org/10.1016/j.meatsci.2012.11.054

Egbert, W.R. and Payne, C.T. (2009). Plant Proteins. In Tarté, R. (Ed.) Ingredients in Meat Products, p. 111129. New York, NY, USA: Springer. https:// doi.org/10.1007/978-0-387-71327-4_5

Feiner, G. (2006). Cooked sausages. Meat Products Handbook, p. 239-286. New York, NY, USA. CRC press Inc. https:// doi.org/10.1533/9781845691721.2.239

Fraser M.D., Fychan, R. and Jones, R. (2005). Comparative yield and chemical composition of two varieties of narrow-leafed lupin (Lupinus angustifolius) when harvested as whole-crop, moist grain and dry grain. Journal of Animal Feed Science, 120, 43-50. https://doi.org/10.1016/ j.anifeedsci.2004.12.014

Güemes-Vera, N., Martinez-Herrera, J., HernandezChavez, J.F., Yanez-Fernandez, J. and Totosaus, A. (2012). Comparison of chemical composition and protein digestibility, carotenoids, tanins and alkaloids content of wild Lupinus varieties flour. Pakistan Journal of Nutrition, 11, 676-682. https:// doi.org/10.3923/pjn.2012.774.780

Hughes, E., Mullen, A.M. and Troy, D.J. (1998). Effects of fat level, tapioca starch and whey protein on frankfurters formulated with $5 \%$ and $12 \%$ fat. Meat Science, 48, 169-180. https://doi.org/10.1016/S03091740(97)00087-9

Kenney, P.B., Kastner, C.L. and Kropf, D.H. (1992). Raw and preheated epimysium and gelatin affect properties of low-salt, low-fat, restructured beef. Journal of Food Science, 57, 551-554. https:// doi.org/10.1111/j.1365-2621.1992.tb08040.x

Osburn, W.N. and Keeton, J.T. (2004). Evaluation of low-fat sausage containing desinewed lamb and konjac gel. Meat Science, 68, 221-233. https:// doi.org/10.1016/j.meatsci.2004.03.001

Porras-Saavedra, J., Güemes-Vera, N., Montañez-Soto, J.L., Fernández-Martínez, M.C. and YañezFernandez, J. (2013). Comparative study of functional properties of protein isolates obtained from three Lupinus species. Advance Bioresearch, 4, 106-116.

Prabhu, G.A., Doerscher, D.R. and Hull, D.H. (2004). Utilization of pork collagen protein in emulsified and whole muscle meat products. Journal of Food Science, 69, 388-392. https://doi.org/10.1111/j.13652621.2004.tb10703.x

Prusinski, J. (2017). White lupin (Lupinus albus L.) Nutritional and health values in human nutrition. A review. Czech Journal Food Science, 35, 95-103. https://doi.org/10.17221/114/2016-CJFS

Ruiz, M.A. and Sotelo, A. (2001). Chemical composition, nutritive value, and toxicology evaluation of Mexican wild lupin. Journal Agriculture and Food Chemistry, 49, 5336-5339. https://doi.org/10.1021/jf010247v

SAS. (1999). SAS User's. Guide: Statistics. $5^{\text {th }}$ ed. USA: SAS Institute Cary

Schilling, M.W., Daigle, S.P., Alvarado, C.Z., Marriott, N.G. and Wang, H. (2005). Effects of collagen addition on the functionality of PSE-like and normal broiler breast in a chunked and formed deli roll. Journal as Muscle Food, 16, 46-53. https:// doi.org/10.1111/j.1745-4573.2004.08104.x

Schilling, M.W., Mink, L.E., Gochenour, P.S., Marriott, N.G. and Alvarado, C.Z. (2003). Utilization of pork collagen for functionality improvement of boneless cured ham manufactured from pale, soft, and exudative pork. Meat Science, 65, 547-553. https:// doi.org/10.1016/S0309-1740(02)00247-4

Schumacher, H., Paulsen, H.M., Gau, A.E., Link, W., Jürgens H.V., Sass O. and Dieterich, R. (2011). Seed protein amino acid composition of important local grain legumes Lupinus angustifolius L., Lupinus luteus L., Pisum sativum L. and Vicia faba L. Plant Breeding, 130, 156-164. https://doi.org/10.1111/ j.1439-0523.2010.01832.x

Sousa, S.C., Fragoso, S.P., Penna, C.R.A., Arcanjo, N.M.O., Silva, F.A.P., Ferreira, V.C.S., Barreto, M.D.S. and Araujo, B.J. (2017). Quality parameters of frankfurters-type sausages with partial 
replacement of fat by hydrolyzed collagen. $L W T-$

Food Science and Technology, 76,76,320-325.

https://doi.org/10.1016/j.lwt.2016.06.034

Szczesniak, A.S. (1963). Classification of textural characteristics. Journal of Food Science, 28:385389. https://doi.org/10.1111/j.13652621.1963.tb00215.x

Tarté, R. (2009). Meat-derived protein ingredients. Ingredients in meat products, p. 145-171. New York, NY, USA: Springer. https://doi.org/10.1007/978-0387-71327-4 7 